\title{
General Receptor For Phosphoinositides 1-Associated Scaffold Protein
}

National Cancer Institute

\section{Source}

National Cancer Institute. General Receptor For Phosphoinositides 1-Associated Scaffold

Protein. NCI Thesaurus. Code C115268.

General receptor for phosphoinositides 1-associated scaffold protein (395 aa, $\sim 43 \mathrm{kDa}$ ) is encoded by the human GRASP gene. This protein plays a role in the localization of cell surface receptors. 